\title{
Impact of the Differences between Brazilian and American Accounting Standards in Performance Indicators of Brazilian Companies with ADRs
}

\author{
Roberto Carlos Klann ${ }^{\dagger}$ \\ Regional University of Blumenau - FURB \\ Ilse Maria Beuren ${ }^{\Omega}$ \\ Regional University of Blumenau - FURB \\ Nelson Hein ${ }^{¥}$ \\ Regional University of Blumenau - FURB
}

\begin{abstract}
The objective of the article is to analyze the impact of the differences between Brazilian and American accounting standards in performance indicators of Brazilian companies that participate in corporate governance. The research is characterized as descriptive, with a quantitative approach using regression and correlation analysis. The sample compose of those 17 companies of Corporate Governance of Bovespa that were presented in the January 2007 negotiation of American Depositary Receipts (ADR's) on the NYSE. Documental research consisted of accounting statements from the year 2005 sent to Bovespa and to the NYSE. The results of the research show divergences on the performance indicators calculated based on the Brazilian and American accounting standards. However, it was evidenced significant correlation between the differences in performance indicators calculated, based on the accounting statements sent to Bovespa and to the NYSE. Therefore, it can be concluded that performance indicators are not affected in any significant way by the divergences in accounting standards between the two countries, not occurring any asymmetry of information in the sample countries between what is divulged on Bovespa and on the NYSE.
\end{abstract}

Keywords: performance indicators; brazilian accounting standards; american accounting standards; corporate governance; brazilian companies.

Received in 12/06/2008; revised in 08/01/2009; accept in 08/15/2009.

Corresponding authors*:

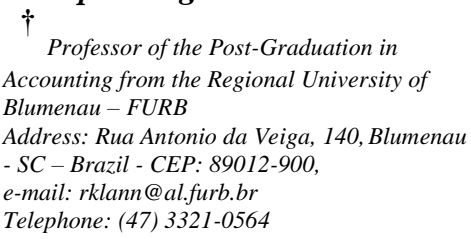

$\Omega$

$\Omega$ Professor of the Post-Graduation in Accounting from the Regional University of Blumenau - FURB

Address: Rua Antonio da Veiga, 140, Blumenau

- SC-Brazil - CEP: 89012-900

e-mail: ilse@furb.br

Telephone: (47) 3321-0564

Editor's note: This paper was accepted by Antonio Lopo Martinez

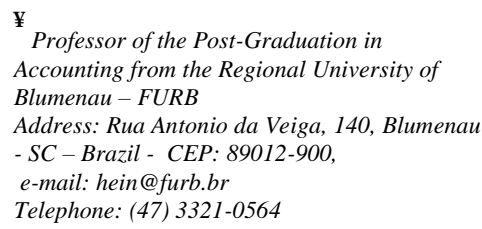

$¥$ Professor of the Post-Graduation in

Accounting from the Regional University of Blumenau - FURB

Address: Rua Antonio da Veiga, 140, Blumenau

- SC - Brazil - CEP: 89012-900,

e-mail: hein@furb.br

Telephone: (47) 3321-0564 


\section{INTRODUCTION}

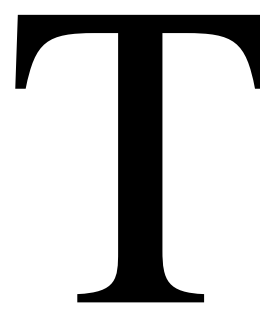

he global competitiveness has led various Brazilian companies to seek alternativesof financing, with less cost, in order to be able to compete in better conditions with foreign competitors. The interest practiced in the Brazilian market and the lower movement of the Brazilian share market in comparison with other charge markets,such as that of the United States, the United Kingdom and Japan, contribute so that the cost of capital of the Brazilian companies is higher in relation to various foreign companies.

To increase the participation of investors in the Brazilian share market practices of corporate governance, amongst other actions, were developed for companies that negotiate their shares on the São Paulo Stock Market (Bovespa), in order to increase the credibility of the share market, by means of total transparency and of mechanisms of protection to the minority shareholders.

On the other hand, some Brazilian companies have also sought to capture resources in the American share market through the launching of American Depositary Receipts (ADR's) on the New York Stock Exchange (NYSE). To be able to act in this market, the companies must periodically remit to the NYSE accounting statements adapted to the American accounting principles generally accepted (Generally Accepted Accounting Principles in the United States - US GAAP).

This conversion can generate asymmetry of information in relation to what is disclosed in the Brazilian share market because the American accounting norms differ in some aspects from the Brazilian accounting Norms. These differences have already been the object of some studies, and one can cite for example that of Niyama (2005) and the survey done by PricewaterhouseCoopers - Brazil (2004). However, this research seeks to identify the impact that these divergences can cause to the performance indicators of the companies, which could lead to the occurrence of problems of asymmetry of information.

These problems began to be studied by means of the Agency Theory which sought to resolve the problems of asymmetry of information and conflicts of interest between the managers and the shareholders of the organizations. The mechanisms of corporative governance, apart from proportioning greater transparency and greater protection to the minority shareholders, also seek to mitigate the asymmetry of information between the diverse stakeholders of the organizations.

Nevertheless, the asymmetry of information generated by the application of different international accounting norms does not depend on the existence or not of conflicts of interests between the managers and the shareholders or of greater or less transparency in the evidencing on the part of the companies. The organizations compromised with the mechanisms of corporative governance need to make these distortions evident, guaranteeing clear information to every kind of investor, national or foreign.

In this context, what is intended with this work is to advance the research on the theme, presenting a comparative study on the impact caused in the performance indicators of the Brazilian companies listed in the levels of corporative governance of Bovespa and with ADR's in the NYSE, in reason of the differences between the Brazilian and American accounting norms, from the information sent by these companies to Bovespa and to the NYSE.

Thus, the objective of the article is to analyze the impact of the differences between the Brazilian and American accounting norms in the performance indicators of Brazilian companies of corporative governance. Based on the statistical analysis, a hypothesis was tested. The null hypotheses $\left(\mathrm{H}_{0}\right)$ and alternative $\left(\mathrm{H}_{1}\right)$ can be thus enunciated: 
$\mathrm{H}_{0}$. : There is no correlation between the calculated performance indicators of Brazilian companies of corporative governance based on the accounting statements sent to Bovespa and the calculated performance indicators of the same companies based on the accounting statements sent to the NYSE.

$\mathrm{H}_{1 .:}$ There is correlation between the calculated performance indicators of Brazilian companies of corporative governance based on the accounting statements sent to Bovespa and the calculated performance indicators of the same companies based on the accounting statements sent to the NYSE.

There not being evidence to reject $\mathrm{H}_{0}$, one will conclude that the differences between the Brazilian accounting norms and the American accounting norms impact in a significant way on the performance indicators of these companies. One can infer that the differences between the Brazilian and American accounting norms generate asymmetry of information between what is evidenced in the Brazilian market and what is evidenced in the American market. In the event $\mathrm{H}_{0}$ is rejected, one can infer that the differences between the Brazilian and American accounting norms do not impact in a significant way the performance indicators of these companies and one can then infer that there is no asymmetry of information between what is evidenced in the Brazilian market and what is evidenced in the American market.

The article is structured into six topics starting with the introduction of the study. Next it makes an incursion into the efforts for harmonizing the international accounting norms and after discourses about the principal divergences between the Brazilian and American accounting norms. Then it describes the method and the procedures of the research. In the sequence, it presents the results of the research highlighting the differences in the performance indicators of the Brazilian companies and the analysis of regression and correlation of the performance indicators. Finally, it presents the conclusions of the research made.

\section{HARMONIZING OF THE INTERNATIONAL ACCOUNTINGNORMS}

One of the challenges of regulatory organs of accounting in the world ambit is to reduce or even eliminate the asymmetry of information evidenced in the reports produced according to the norms of different countries.

For this, diverse international organisms, such as the International Accounting Standards Board (IASB), the International Federation of Accountants (IFAC), the United Nations and The International Organization of Securities Commission (IOSCO) have made efforts for an international harmonizing. The role of these international organisms is to contribute to the establishing of standards of high quality that can serve as a basis for the different countries. Now the role of the national organisms is to try to harmonize their local standards with the international norms.

The asymmetry of information, caused by differences of accounting normalization between the countries, can prejudice the investors' decisions. With a globalized economy, the accounting information of the companies is analyzed by different investors in the most diverse locations of the world. To minimize or eliminate these differences can help the investors in the analysis of this information, in any market where the company is negotiating its shares.

In spite of all the efforts in the sense of international harmonizing of the accounting norms, it is possible that a Brazilian company, for example, presents favorable performance indicators according to the Brazilian accounting norms, but does not present the same performance if the indexes are calculated based on the accounting statements prepared to the Security Exchange Commission (SEC), according to the American norms. 
These differences occur, according to Niyama (2005), because the language is not uniform. The non uniformity exists because each country has its own criterion to recognize and measure each transaction. Some studies have already been developed trying to classify the national accounting systems in groups, considering the political, social, cultural and economical environment of each country and their possible impacts in the respective accounting systems.

On commenting about the accounting harmonizing, Weffort (2005, p. 22) cites that it can occur in two ambits: in the practices (harmonizing of fact) and in the norms (harmonizing of law). The first refers to "an effective application of the procedures internationally recommended in the local accounting practices". The second "is with respect, in a simplified way, to the incorporation in the national legislation of the international norms, turning determined accounting procedures obligatory, permitted or prohibited".

According to Weffort (2005), these two ambits of the harmonizing can occur concomitantly in a determined country, but this is not necessarily a rule. The use of differenced accounting practices by the countries can occur for different reasons. Niyama (2005) cites various studies done about the harmonizing of the international accounting norms in which the causes of the differences of accounting practices adopted by the countries are enumerated. In Table 1 is presented a synthesis of these researches cited by the author.

\begin{tabular}{|c|c|c|c|c|c|}
\hline Causes/Studies & $\begin{array}{c}\text { Study } 5 \\
\text { Saudagara } \\
\text { n (2004) }\end{array}$ & $\begin{array}{c}\text { Study } 4 \\
\text { Elliot e } \\
\text { Elliot } \\
(\mathbf{2 0 0 2})\end{array}$ & $\begin{array}{l}\text { Study } 3 \\
\text { Belkaoui } \\
(\mathbf{2 0 0 0 )}\end{array}$ & $\begin{array}{c}\text { Study } 2 \\
\text { Nobes } \\
(\mathbf{1 9 9 8 )}\end{array}$ & $\begin{array}{c}\text { Study 1 } \\
\text { Radebaug } \\
\text { e Gray } \\
(1993)\end{array}$ \\
\hline National legal system & $\mathrm{X}$ & $\mathrm{X}$ & $\mathrm{X}$ & $\mathrm{X}$ & $\mathrm{X}$ \\
\hline Model of capturing resources (share market or & $\mathrm{X}$ & $\mathrm{X}$ & & $\mathrm{X}$ & $\mathrm{X}$ \\
\hline Influence of the State in the Accounting & & $\mathrm{X}$ & & & \\
\hline The influence of the accounting profession & $\mathrm{X}$ & $\mathrm{X}$ & & $\mathrm{X}$ & $\mathrm{X}$ \\
\hline Level of development of the Accounting Theory & $\mathrm{X}$ & $\bar{X}$ & & $\bar{X}$ & \\
\hline Accidents of history (wars) & & $\mathrm{X}$ & & $\mathrm{X}$ & \\
\hline Knowledge of the language & & $\mathrm{X}$ & & $\mathrm{X}$ & \\
\hline $\begin{array}{l}\text { Type of regime and structure of the accounting } \\
\text { statements }\end{array}$ & $\mathrm{X}$ & & & & $\mathrm{X}$ \\
\hline Type of companies & $\mathrm{X}$ & & & & $\mathrm{X}$ \\
\hline Level of requirement & $\mathrm{X}$ & & & & \\
\hline Level of inflation & $\mathrm{X}$ & & & $\mathrm{X}$ & $\mathrm{X}$ \\
\hline $\begin{array}{l}\text { Economic and political linking with other } \\
\text { countries }\end{array}$ & $\mathrm{X}$ & & & & $\mathrm{X}$ \\
\hline Quality of the accounting education & $\mathrm{X}$ & & & & $\mathrm{X}$ \\
\hline Culture & & & & $\mathrm{X}$ & $\bar{X}$ \\
\hline Economic growth and development & & & $\mathrm{X}$ & $\mathrm{X}$ & $\mathrm{X}$ \\
\hline Social environment & & & & $\mathrm{X}$ & $\bar{X}$ \\
\hline Level of business activity & & & $\mathrm{X}$ & & $\mathrm{X}$ \\
\hline Taxation & & & & $\mathrm{X}$ & $\mathrm{X}$ \\
\hline Political system & & & $\mathrm{X}$ & $\mathrm{X}$ & $\bar{X}$ \\
\hline History and geography & & & & $\mathrm{X}$ & \\
\hline Religion & & & & $\mathrm{X}$ & \\
\hline $\begin{array}{l}\text { Heritage of having been a colony of another } \\
\text { country }\end{array}$ & & & & $\mathrm{X}$ & \\
\hline
\end{tabular}

Chart 1 - Causes of the international differences in the financial reporting

Source: adapted from Niyama (2005, p. 22-24). 
When analyzing Table 1, one sees that the principal causes of international differences in the financial reports are:

a) legal system of the country-cited in all the studies analyzed;

b) model of resources capturing (share market or financial entities) - cited in 4 of the 5 studies;

c) the influence or status of the accounting profession - also cited by 4 studies.

As to the legal system of the country, Niyama (2005) relates that it can be classified in two currents: common-law and code-law. The first current, predominantly in countries such as Great Britain, the United States amongst others, has as principle that all that is not prohibited is accepted. The accounting statements of these countries are based on the true and fair value. Creativity is used to interpret the "spirit" of the law, which can be evasive and result in manipulation or advantage taking of legal loopholes. The author cites that it is propitious for innovations in terms of financial reporting.

The second current, in its turn, known as legalistic, predominates in countries such as Germany, Japan and France. It has as principle that everything has to be written. With this, one has less flexibility in the presentation of the accounting statements. The emphasis is on the creditors whilst in the common law system more importance is given to the shareholders (NIYAMA, 2005).

As to the model of resources capturing, it influences the accounting statements, because in countries where the share market is strong, the statements of the companies will be directed principally to the shareholders. Now, in countries where the larger part of the resources capturing is done via loans in financial institutions, the accounting statements will be directed towards the creditors. Each type of user (shareholder, creditor, government, amongst others), is interested in different information.

In relation to the level of influence or status of the accounting profession, Niyama (2005, p. 28) comments that "the status of the accounting profession ends up being positively influenced in the quality of the accounting statements prepared and the auditing reports are considered, in a general way, as more reliable and independent".

Analyzing the Brazilian situation, one observes that the accounting profession is represented by the Federal Council of Accountancy (CFC) and by the Institute of Independent Auditors of Brazil (IBRACON). Nevertheless, none of them have sufficient force to influence the publishing of accounting norms in the country. The CFC created a work group that regularly publishes Brazilian Norms of Accountancy (NBC), but the organ has no authority to oblige the companies to follow these norms (NIYAMA, 2005).

Therefore, one can infer that in countries where the accounting profession counts on a higher status and, therefore, with greater influence in the accounting practices, the quality of the accounting statements is inherent and respected, increasing the reliability on them before the users of the accounting information.

\section{PRINCIPAL DIVERGENCES BETWEEN THE BRAZILIAN AND AMERICAN ACCOUNTING NORMS}

PricewaterhouseCoopers - Brazil prepared a Pocket Guide about the principal divergences between the international norms (IFRS), American (US GAAP) and the Brazilian norms of accountancy (BR GAAP) (www.pwc.com.br).

In the present study the divergences between the American norms (US GAAP) and the Brazilian norms of accountancy are of interest (BR GAAP). In Table 2, the principal differences between US GAAP and BR GAAP as to the accounting conceptual structure are presented. 


\begin{tabular}{l|l}
\hline Divergences & Accounting norms \\
\hline \multirow{2}{*}{$\begin{array}{l}\text { Basis } \begin{array}{l}\text { accounting } \\
\text { value }\end{array} \\
\text { of }\end{array}$} & $\begin{array}{l}\text { US GAAP - re-evaluations are not permitted, except in case of derivative financial } \\
\text { instruments and some other financial instruments that should or may be evaluated at fair } \\
\text { value. }\end{array}$ \\
\cline { 2 - 2 } $\begin{array}{l}\text { Deviation } \\
\text { accounting } \\
\text { practice }\end{array}$ & $\begin{array}{l}\text { US GAAP - historical cost, but items of the fixed assets can be re-evaluated. } \\
\text { norm when this is essential so that the financial statements are adequately presented, } \\
\text { however, in practice, it is not adopted. }\end{array}$ \\
\cline { 2 - 2 } & $\begin{array}{l}\text { BR GAAP - does not foresee situations for the deviation, but uses the concept of the } \\
\text { essence over the form. }\end{array}$ \\
\hline
\end{tabular}

\section{Chart 2 - Principal differences between US GAAP and BR GAAP as to the accounting} conceptual structure

Source: adapted from PricewaterhouseCoopers (2006, p. 1-11).

In relation to the basis of accounting value, the norms follow the same basic principle, that is, they use the cost as basis of accounting value. Nevertheless, in specific situations, the American norms accept the use of the concept of fair value. Now in Brazil, the application of this concept does not exist. Only some fixed assets can be re-evaluated.

As to the deviations of accounting practices, the American norms accept this practice when they contribute to a better presentation of the results. Now in Brazil there is no provision in the norms for this procedure, with the exception of the use of the principle of the essence over the form.

As to the financial statements (accounting), the principal differences found between the US GAAP and the BR GAAP are presented in Table 3, in accordance with the survey made by PricewaterhouseCoopers - Brazil. 


\begin{tabular}{|c|c|}
\hline Divergences & Accounting norms \\
\hline \multirow{2}{*}{$\begin{array}{l}\text { Currency of } \\
\text { measuring and } \\
\text { presentation of } \\
\text { the financial } \\
\text { statements }\end{array}$} & $\begin{array}{l}\text { US GAAP - The rules of the SEC permit non American companies registered in that } \\
\text { commission to choose the currency of presentation of the financial statements. }\end{array}$ \\
\hline & $\begin{array}{l}\text { BR GAAP - the financial statements must be presented in the currency of the country. } \\
\text { Consolidated companies that operate in other countries have their financial statements } \\
\text { measured using the functional currency of the respective company and, later, converted to } \\
\text { the country currency. }\end{array}$ \\
\hline \multirow{2}{*}{$\begin{array}{l}\text { Net Worth } \\
\text { Balance Sheet }\end{array}$} & $\begin{array}{l}\text { US GAAP - can present a classified or not balance sheet. The items presented separately } \\
\text { generally follow a decreasing order of liquidity. }\end{array}$ \\
\hline & $\begin{array}{l}\text { BR GAAP - the assets and liabilities are divided into current and non-current groups and } \\
\text { presented in decreasing order of liquidity amongst these groups. }\end{array}$ \\
\hline \multirow{2}{*}{$\begin{array}{l}\text { Income } \\
\text { Statement }\end{array}$} & $\begin{array}{l}\text { US GAAP - permit the presentation in running format, in which the expenses are classified } \\
\text { by function and deducted from the total revenues, or by sub-totals, in which the income and } \\
\text { expenses are classified in groups. The expenses must be presented by function. }\end{array}$ \\
\hline & $\begin{array}{l}t \text { for the non-operational items and by requiring the } \\
\text { s. }\end{array}$ \\
\hline \multirow{2}{*}{$\begin{array}{l}\text { Statement of } \\
\text { Cash Flow }\end{array}$} & $\begin{array}{l}\text { US GAAP - classification in category with specific orientation } \\
\text { each category. They also permit the use of the direct and indirec }\end{array}$ \\
\hline & $\begin{array}{l}\text { BR GAAP - do not require the presentation. When presented voluntarily, the rules are } \\
\text { similar to the IFRS. }\end{array}$ \\
\hline \multirow{2}{*}{$\begin{array}{l}\text { Changes in the } \\
\text { accounting } \\
\text { policies }\end{array}$} & $\begin{array}{l}\text { US GAAP - generally require the inclusion of the effect on the income statement of the } \\
\text { current period. They require the disclosure of the comparative information "pro-forma". } \\
\text { They require retroactive adjustments in specific situations. }\end{array}$ \\
\hline & $\begin{array}{l}\text { BR GAAP - normally they are treated as adjustment of the initial balance of the profits or } \\
\text { losses accumulated from the current year. There is no correction or re-presentation of } \\
\text { comparative information. }\end{array}$ \\
\hline
\end{tabular}

Chart 3 - Principal differences between US GAAP and BR GAAP as to the accounting statements

Source: adapted from PricewaterhouseCoopers (2006, p. 12-25).

In relation to the financial statements (accounting), the principal differences observed in Table 3 refer to the structure of the Net Worth Balance Sheet, to the Statement of Cash Flow and to the changes in the accounting policies.

Concerning the structure of the Balance Sheet, the American norms foresee the separation of the assets and liabilities in the balance sheet in current and non-current. Now the Brazilian norms present another sub-division of these groups with the assets separated into current, long term realizable and permanent. The liabilities are divided into current and noncurrent.

Another important difference refers to the Statement of Cash Flow (DFC). This statement is obligatory according to the US GAAP. Now in Brazil the DFC is not obligatory, being substituted by the DOAR. Law no. $11.638 / 07$, of December $18^{\text {th }}, 2007$, in its art. 176 , item IV, determined the substitution of the Statement of the Origins and Applications of Resources (DOAR) for the Statement of Cash Flow (DFC).

As to the changes of accounting policies, the US GAAP foresees the recognition of the adjustment in the results of the current period. In Brazil, the adjustments are made in the initial balance of the profits and/or losses accumulated in the current year.

In relation to the combination of business, the principal differences pointed out by PricewaterhouseCoopers - Brazil are presented in Table 4. 


\begin{tabular}{|c|c|}
\hline Divergences & Accounting norms \\
\hline \multirow{2}{*}{$\begin{array}{l}\text { Fair value of } \\
\text { the assets and } \\
\text { liabilities in } \\
\text { the acquisition, } \\
\text { premium and } \\
\text { discount }\end{array}$} & $\begin{array}{l}\text { US GAAP - require the recognition by the buyer of all the assets and liabilities acquired at } \\
\text { their fair value. The premium or discount originated from the acquisition corresponds to the } \\
\text { difference between the fair value of the assets given in payment (cash, shares) and the fair } \\
\text { value of all the assets and liabilities acquired. They have specific rules for ongoing projects } \\
\text { or research and development acquired (generally must be posted as expense in the results). }\end{array}$ \\
\hline & $\begin{array}{l}\text { BR GAAP - only the assets and liabilities registered in the balance sheet of the acquired } \\
\text { company are recognized in the buyer at the original accounting value, except for the surplus } \\
\text { value attributed to the fixed asset that must be recognized as part of the cost of the asset in } \\
\text { the circumstances of incorporations. The premium or discount originated from the } \\
\text { acquisition corresponds to the difference between the amount paid by the company acquired } \\
\text { and the original accounting value of the assets and liabilities registered in its balance sheet. }\end{array}$ \\
\hline \multirow{2}{*}{$\begin{array}{l}\text { Premium and } \\
\text { intangible } \\
\text { assets } \\
\text { subsequent } \\
\text { treatment to } \\
\text { the acquisition }\end{array}$} & $\begin{array}{l}\text { US GAAP - certain intangible assets of contractual origin, separable and with finite useful } \\
\text { life must be amortized. Premium and intangible assets with undefined life are not } \\
\text { amortized, but have their value of recuperation calculated annually and compared to the } \\
\text { accounting value. Whenever the value of recuperation is less than the accounting value, a } \\
\text { loss must be recognized in the results of the period. }\end{array}$ \\
\hline & $\begin{array}{l}\text { BR GAAP - the Premium is amortized in a period not greater than } 10 \text { years, except when } \\
\text { resulting from the acquisition of the right of exploration, concession or permission } \\
\text { delegated by the public power, being amortized, in this case, in the period of the respective } \\
\text { concession. }\end{array}$ \\
\hline
\end{tabular}

\section{Chart 4 - Principal differences between US GAAP and BR GAAP as to combination of business}

Source: adapted from PricewaterhouseCoopers (2006, p. 36-43).

One of the principal differences observed in Table 4 refers to the fair value of assets and liabilities in the acquisition of companies. The American norms establish that the assets and liabilities acquired must be evaluated at fair value, whereas the Brazilian norms foresee the use of the original accounting value.

Another important difference of treatment refers to the premium and to the intangible assets. The American norms establish that the Premium and the intangible assets with undefined life do not suffer amortization, but the test of impairment over these items is done annually, in order to check if the value of recuperation is greater than the accounting value. In the event it is not, a loss must be recognized. The Brazilian norms do not establish the test of impairment. The premium is generally amortized in a period not greater than ten years.

As to the recognition of assets and liabilities, the Study of PricewaterhouseCoopers Brazil points out as principal differences the items presented in Table 5. 


\begin{tabular}{|c|c|}
\hline Divergences & Accounting norms \\
\hline \multirow[t]{2}{*}{$\begin{array}{l}\text { Intangible } \\
\text { assets acquired } \\
\text { from third } \\
\text { parties }\end{array}$} & $\begin{array}{l}\text { US GAAP - require the capitalization if the criterion of recognition are satisfied. They } \\
\text { must be amortized considering their useful life. Assets with undefined useful life are not } \\
\text { amortized but must, at least annually, have the value or recuperation calculated and } \\
\text { compared with the accounting value. In the event the recoverable value is less than the } \\
\text { accounting value, a loss must be registered against the results of the period. Re-evaluations } \\
\text { are not permitted. The gains or losses calculated in the sale or write off of the intangible } \\
\text { assets are registered as operational results. }\end{array}$ \\
\hline & $\begin{array}{l}\text { BR GAAP - generally they are classified in the group of fixed or differed assets and } \\
\text { amortized according to their useful life. Re-evaluations of intangibles are not permitted. } \\
\text { The gains or losses calculated in the sale or write off of the intangibles are registered as non } \\
\text { operational results. }\end{array}$ \\
\hline \multirow[b]{2}{*}{$\begin{array}{l}\text { Intangible } \\
\text { assets } \\
\text { generated } \\
\text { internally }\end{array}$} & $\begin{array}{l}\text { US GAAP - the costs of research and development are posted as expenses in the results of } \\
\text { the period when incurred. Some costs of software and website development must be } \\
\text { capitalized. }\end{array}$ \\
\hline & $\begin{array}{l}\text { BR GAAP - operational expenses, expenses with the launching of new products or } \\
\text { productive processes or related to the period in which the normal capacity of production of } \\
\text { the company had not yet been reached, are capitalized as deferred assets, as long as they } \\
\text { contribute to the generation of future benefits. Such expenses are amortized for a period not } \\
\text { greater than ten years. The gains or losses calculated in the sale or write off of intangible } \\
\text { assets are registered as non operational expenses. }\end{array}$ \\
\hline \multirow{2}{*}{$\begin{array}{l}\text { Leasing } \\
\text { classification }\end{array}$} & $\begin{array}{l}\text { US GAAP - is classified as financial when substantially all the risks and benefits of the } \\
\text { propriety of the good are transferred to the lessee. In this case the operation is equivalent to } \\
\text { a financing for the acquisition of the good. The substance must prevail over the form. }\end{array}$ \\
\hline & $\begin{array}{l}\text { BR GAAP - local practices encourage, but do not oblige, the registry of the financial } \\
\text { leasing contracts as financing. In practice, the majority of the leasing contracts are treated } \\
\text { as operational. The companies must however disclose, in a note, the data about the } \\
\text { equipment acquired through the leasing contract. }\end{array}$ \\
\hline \multirow{2}{*}{$\begin{array}{l}\text { Losses by } \\
\text { reduction of } \\
\text { the recoverable } \\
\text { value of the } \\
\text { assets } \\
\text { (Impairment) }\end{array}$} & $\begin{array}{l}\text { US GAAP - for assets kept for use in the operations, the calculation of the value in use has } \\
\text { cash flows not discounted as a basis. If the value in use is less than the accounting value, a } \\
\text { loss is accounted for using the greater between the market value and the cash flows } \\
\text { discounted at present value. }\end{array}$ \\
\hline & $\begin{array}{l}\text { BR GAAP - Whenever the accounting value of a good is greater than the recoverable } \\
\text { value, a loss must be registered to reduce the accounting value of recovery. However, there } \\
\text { are no detailed rules for the identification and calculation of the losses by reduction of the } \\
\text { recovery value. The losses must be recognized only when considered non temporary. } \\
\text { Losses by reduction to the recoverable value are registered as non operational expenses in } \\
\text { the results of the period. }\end{array}$ \\
\hline \multirow{2}{*}{$\begin{array}{l}\text { Financial } \\
\text { Assets } \\
\text { measuring }\end{array}$} & $\begin{array}{l}\text { US GAAP - depends on the classification. Financial assets kept up to due date or } \\
\text { originated by the very company are registered at amortized cost. Other financial assets are } \\
\text { registered at fair value. }\end{array}$ \\
\hline & $\begin{array}{l}\text { BR GAAP - are registered at the cost deducted from eventual losses. Gains and losses are } \\
\text { always recognized in the results. }\end{array}$ \\
\hline
\end{tabular}

Source: adapted from PricewaterhouseCoopers (2006, p. 50-76).

In relation to the intangible assets acquired from third parties, the principal difference is in the use of the test of impairment by the American norms, which does not occur in Brazil. Another important difference consists on the recognition of the gains and losses in the sale or write off of these assets. The US GAAP treats these gains and losses as operational result, whereas in Brazil they are treated as non operational results. The SFAS 142 (FASB) establishes that the costs deducted from the residual value of intangible assets with finite useful life must be amortized for its useful life, whereas the intangible assets with indefinite useful life must not be amortized. 
Concerning the intangible assets generated internally in the company, the expenses with research and development are generally treated as expenses by the American norms. In Brazil, these expenses are activated and amortized in a maximum period of tem years in accordance with the company legislation.

The financial leasing is classified in the liabilities, in accordance with the US GAAP (SFAS 2, FASB). In Brazil, although there is an incentive to the recognition as financing, in practice these leasing are treated as rentals. The data of the contract must be evidenced only in explanatory notes.

As to the test of impairment, the American norms have defined rules about its annual calculation. In Brazil, although there exists the concept of recoverable value of the assets, or adjustment to the market value when it is less than the accounting value, there do not exist precise rules about the calculation of the recoverable value of the assets, nor as to their periodicity.

The financial assets are registered at the amortized cost or at the fair value, depending on their classification in accordance with the American norms. The gains or losses can be recognized in the result or in the net worth, depending on the case. In Brazil, they are always registered at the cost value deducted from the losses, being that the gains or losses are always recognized in the result.

In relation to the derivatives, hedge operations and other matters, the principal differences between the US GAAP and the Brazilian norms of accounting pointed out in the Study of PricewaterhouseCoopers - Brasil are presented in Table 6.

\begin{tabular}{l|l}
\hline Divergences & Accounting norms \\
\hline \multirow{4}{*}{$\begin{array}{l}\text { Derivatives } \\
\text { and "Hedge" } \\
\text { operations }\end{array}$} & $\begin{array}{l}\text { US GAAP - require recognition at the fair value. Gains and losses are recognized in the } \\
\text { DRE, except for hedges of cash flow considered effective, whose gains and losses are } \\
\text { deferred in the PL. Apart from this, it does not require the adjustment of the base value of } \\
\text { the hedge operations of cash flow of foreseen transactions. }\end{array}$ \\
\cline { 2 - 2 } & $\begin{array}{l}\text { BR GAAP - are evaluated at the value of the curve of the operations and have gains and } \\
\text { losses always directly recognized in the results of the period. }\end{array}$ \\
\hline \multirow{4}{*}{$\begin{array}{l}\text { Operations in } \\
\text { discontinuity }\end{array}$} & $\begin{array}{l}\text { US GAAP - require the disclosure of the discontinued operations and kept for sale as a } \\
\text { separate item in the DRE, before the extraordinary items and of the cumulative effect of the } \\
\text { accounting changes. Assets and liabilities kept segregated in the net worth balance sheet. }\end{array}$ \\
\cline { 2 - 2 } & $\begin{array}{l}\text { BR GAAP - in practice they are disclosed at less detailed levels that those required by the } \\
\text { US GAAP. }\end{array}$ \\
\hline
\end{tabular}

\section{Chart 6 - Principal differences between US GAAP and BR GAAP as to the derivatives, hedge operations and other matters}

Source: adapted from PricewaterhouseCoopers (2006, p. 78-91).

The hedge operations are evaluated at fair value, in accordance with the US GAAP. Gains and losses are recognized in the result, except in hedges of effective cash flow, whose gains and losses are deferred in PL. The SFAS 133 (FASB) establishes the principles of recognition and measuring of the financial assets, of the financial liabilities, of some contracts or purchase and non financial items. Now in Brazil, these operations are evaluated at the value of the curve of the operations, the gains and losses always being recognized directly in the result.

As to the operations in discontinuity, the US GAAP requires the disclosure in separate items in the DRE. In Brazil the disclosure of this information is done with less degree of details that the American norms.

The divergences presented in Tables 2 to 6 can impact on the values shown in the accounting statements. A same company can present different compositions of assets and 
liabilities and divergent results, on analyzing their accounting statements sent to Bovespa and to the NYSE.

These differences can alter the value of the performance indicators, calculated from these statements. With this, there can exist an asymmetry of information. Depending on the location of the users they could have different impressions of the same company. This means that a company can present very different indicators of liquidity, indebtedness or profitability, depending on the statement that is being analyzed, if remitted to Bovespa or to the NYSE.

\section{METHOD AND PROCEDURE OF THE RESEARCH}

The present research is characterized as descriptive. Gil (2002) comments that the descriptive research has as objective to describe the characteristics of a determined population or phenomenon or to establish relationships between variables. In this sense, one seeks to analyze the impact of the differences between the Brazilian and American accounting norms on the performance indicators of Brazilian companies listed in the levels of corporative governance of Bovespa.

In relation to the approach of the problem the research is characterized as quantitative. According to Boudon (1989, p. 24), "the quantitative researches can be defined as those that permit, in a group of elements, the gathering of comparable information between one element and another". This comparability of the information is what permits the quantitative analysis of the data. Therefore, for their application, the existence of a group of more or less comparable elements is essential.

The population of the research covers the 81 Brazilian companies listed in Levels 1 and 2 and in the New Market of Corporative Governance of the Stock Market of São Paulo (Bovespa) (www.bovespa.org.br), in January 2007. The companies listed in the levels of Corporative Governance of Bovespa were selected considering that these companies had commitment with transparency and responsibility of the information given to the public and, therefore, tend to transmit greater reliability.

The sample selected for the research is of the intentional type in which, according to Richardson (1999), the elements of the sample are intentionally related in accordance to the characteristics prescribed in the plan and in the research hypotheses. The criterion used was the companies did business of American Depositary Receipts (ADR's) in the NYSE. Based on this criterion the 17 Brazilian companies listed in the levels of Governance of Bovespa and with ADR's ion the NYSE were selected.

The data was collected from the accounting statements sent to Bovespa and to the NYSE, by the companies' components of the sample, referent to the year 2005. Based on these reports, three indicators of indebtedness were calculated, two of liquidity and two indicators of profitability chosen randomly, listed in Table 7. 


\begin{tabular}{|c|c|c|}
\hline Group of & Performance Indicator & Formula \\
\hline \multirow{3}{*}{$\begin{array}{l}\text { Indicators of } \\
\text { Indebtedness }\end{array}$} & Indebtedness & $E N D=\begin{array}{l}P T \\
P L\end{array}$ \\
\hline & Financial Dependence & $D F=\begin{array}{l}P T \\
A T\end{array}$ \\
\hline & Investing of Permanent Capital & $I C P=\begin{array}{c}A P \\
P L+P E L P\end{array}$ \\
\hline \multirow{2}{*}{$\begin{array}{l}\text { Indicators of } \\
\text { Liquidity }\end{array}$} & General Liquidity & $L G=\begin{array}{l}A C+A R L P \\
P C+P E L P\end{array}$ \\
\hline & Current Liquidity & $L C=\begin{array}{l}A C \\
P C\end{array}$ \\
\hline \multirow{2}{*}{$\begin{array}{l}\text { Evaluation of } \\
\text { the Economic } \\
\text { Performance }\end{array}$} & Return on the Asset - ROA & $R O A=\begin{array}{c}L O \\
A T-L L\end{array}$ \\
\hline & Return on the Net Worth - RSPL & $R S P L=\begin{array}{c}L L \\
P L-L L\end{array}$ \\
\hline \multicolumn{3}{|c|}{$\begin{array}{lc}\text { Legend: } & \text { LL }=\text { Net profit } \\
\text { AC }=\text { Current Assets } & \text { LO }=\text { Operational profit } \\
\text { AP }=\text { Permanent Assets } & \\
\text { ARLP }=\text { Long term Receivable Assets } & \\
\text { AT }=\text { Total Assets } & \\
\end{array}$} \\
\hline
\end{tabular}

\section{Chart 7 - Performance indicators used in the research}

Source: adapted from Assaf Neto (2002).

After the application of the performance indicators of Table 7 in the accounting statements of 2005 of the companies researched, the percentage differences were raised between the indicators of the DC sent to Bovespa and to the NYSE. Next, by means of quantitative approach, the data collected and tabulated was analyzed with the use of the statistical technique of regression and correlation.

The analysis of regression was used principally with the objective of forecast. Its purpose is the development of a statistical model that can be used to foresee the value of a dependent variable (or of response), based on the values of at least one independent variable (or explicative) (MAROCO, 2003).

As to the analysis of correlation, Spiegel (1993) conceives it as the degree in relationship between the variables where it determines how well a linear equation, or of another kind, explains the relationship between the variables. Contrary to the analysis of regression, the analysis of correlation is used to measure the force of the association between the numerical variables,

To prove the results found with the analysis of regression and correlation, the QSquared Test of significance was also applied, with 95\% reliability and a degree of liberty. According to Siegel (1975, p. 47), the Q-Squared Test "tests if the frequencies observed are sufficiently close to those expected to justify their occurrence under $\mathrm{H}_{0}$ ".

Concerning the limitations of the research done, one observes that they result from the strategy defined for the research. One of them is due to the sample selected, being that the results apply only to these companies. Another results from the performance indicators chosen, being that the results cannot be the same if indicators different from those selected are 
considered. Nevertheless, it is a question of a Study which can be amplified in later researches with other research strategies.

\section{DESCRITION AND DATA ANALYSIS}

In the description and analysis of the data, the percentage differences are initially presented in the performance indicators of the Brazilian companies, calculated with basis on the reports sent to Bovespa and to the NYSE. Next, the regress and correlation analysis of these performance indicators were touched on.

\subsection{Differences in the performance indicators of the Brazilian companies}

Based on the accounting statements (DC) of Brazilian companies of 2005, sent to Bovespa and to the NYSE, the performance indicators were calculated. In the sequence, the percentage differences between the indicators of the DC sent to Bovespa and the indicators of the DC sent to the NYSE were raised. These differences are presented in Table 1.

Table 1 - Percentage differences in the performance indicators calculated with basis on the accounting statements sent to Bovespa and to the NYSE

\begin{tabular}{l|l|l|l|l|l|l|l}
\hline $\begin{array}{l}\text { DIFFERENCE \% IN THE INDICATORS } \\
\text { 2005 (BOVESPA TO NYSE) }\end{array}$ & END & DF & ICP & LG & LC & ROA & RSPL \\
\hline Aracruz Celulose e Papel S/A & 0.38 & 0.17 & 0.02 & $(0.14)$ & $(0.12)$ & $(0.09)$ & 0.85 \\
Banco Bradesco S/A & 0.06 & 0.01 & 0.44 & $(0.00)$ & $(0.49)$ & $(0.55)$ & $(0.13)$ \\
Banco Itaú Holding Financeira S/A & 0.32 & 0.03 & $(0.53)$ & 0.01 & $(0.47)$ & $(0.38)$ & 0.20 \\
Brasil Telecom Participações S/A & 0.49 & 0.14 & $(0.13)$ & 0.01 & 0.20 & 1.01 & $(1.21)$ \\
Braskem S/A & $(0.30)$ & $(0.09)$ & 0.13 & $(0.06)$ & $(0.01)$ & $(0.40)$ & $(0.49)$ \\
Cia. Brasileira de Distribuição & 0.02 & 0.01 & $(0.02)$ & 0.05 & $(0.07)$ & $(0.64)$ & $(0.08)$ \\
Cia. Energética de Minas Gerais - CEMIG & 0.35 & 0.13 & $(0.05)$ & 0.02 & $(0.06)$ & 0.56 & 0.59 \\
Cia. de Saneamento Básico do Estado de São & $(0.37)$ & $(0.18)$ & $(0.07)$ & 0.81 & 0.01 & $(0.11)$ & $(0.13)$ \\
Paulo - SABESP & & & & & & & \\
Cia. Vale do Rio Doce & 0.38 & 0.17 & 0.03 & $(0.03)$ & $(0.25)$ & 0.05 & 0.13 \\
CPFL Energia S/A & 0.29 & 0.10 & $(0.04)$ & 0.02 & 0.00 & $(0.15)$ & 0.26 \\
Gerdau S/A & 0.06 & 0.02 & $(0.01)$ & $(0.00)$ & $(0.02)$ & 0.05 & 0.15 \\
Gol Linhas Aéreas Inteligentes S/A & 0.08 & 0.05 & 0.20 & $(0.09)$ & $(0.01)$ & $(0.14)$ & $(0.06)$ \\
Perdigão S/A & $(0.01)$ & $(0.00)$ & 0.03 & $(0.01)$ & $(0.02)$ & $(0.01)$ & $(0.01)$ \\
Sadia S/A & $(0.04)$ & $(0.01)$ & 0.08 & $(0.03)$ & 0.05 & 0.11 & 0.13 \\
Ultrapar Participações S/A & $(0.05)$ & $(0.03)$ & 0.05 & $(0.00)$ & 0.08 & $(0.08)$ & $(0.02)$ \\
Unibanco Holdings S/A & 0.05 & 0.00 & 0.04 & 0.01 & $(0.41)$ & $(0.58)$ & 0.19 \\
Votorantim Celulose e Papel S/A & 0.13 & 0.06 & $(0.01)$ & $(0.06)$ & $(0.08)$ & $(0.11)$ & $(0.15)$ \\
\hline Source: research data.
\end{tabular}

Source: research data.

Table 1 demonstrates that the percentage variations in the performance indicators are heterogeneous. There are positive and negative variations. Apart from this some companies have significant differences in certain indicators and irrelevant in others .

For example, the company Aracruz Celulose S/A has a positive variation in the Return on Net Worth (RSPL) of $85 \%$, that is, this index according to the accounting statements sent to the NYSE is $85 \%$ higher than the index calculated based on the reports sent to Bovespa.

On the other hand, Brasil Telecom Participações S/A had negative variations in this same index of $121 \%$. Now, companies such as Perdigão and Ultrapar had minimum variations of approximately $1 \%$ and $2 \%$ respectively. 
To facilitate a global analysis of the impact of the Divergences between the Brazilian and American accounting norms in the performance indicators of the companies, the analysis of regression and of correlation are used in the sequence.

\subsection{Analysis of regression and correlation of the performance indicators}

In the analysis of regress and of correlation it was sought to verify the relationship between the performance indicators calculated based on the Brazilian accounting norms and the performance indicators calculated based on the American accounting norms. This analysis is presented in Table 8 .

\begin{tabular}{l|l|l|l|l|l}
\hline $\begin{array}{c}\text { Indicator } \\
\text { (US GAAP) }\end{array}$ & $\begin{array}{c}\text { Coefficient of } \\
\text { Correlation }\end{array}$ & Significant & $\begin{array}{c}\text { Correlated } \\
\text { indicator (BR } \\
\text { GAAP) }\end{array}$ & Equation of Regression & $\begin{array}{c}\text { Outliers } \\
\text { Cases }\end{array}$ \\
\hline END & $98,90 \%$ & Yes & END & $0,917642 \mathrm{END}+0,025458$ & 3 and 5 \\
\hline DF & $94,87 \%$ & Yes & DF & $0,990948 \mathrm{DF}-0,0101174$ & 8 \\
\hline ICP & $98,74 \%$ & Yes & ICP & $1,02 \mathrm{ICP}-0,008378$ & 4 and 5 \\
\hline LG & $99,42 \%$ & Yes & LG & $1,11963 \mathrm{LG}-0,0980838$ & 1 \\
\hline LC & $86,41 \%$ & Yes & LC & $0,816925 \mathrm{LC}+0,546291$ & 2 and 3 \\
\hline ROA & $96,56 \%$ & Yes & ROA & $0,881753 \mathrm{ROA}+0,0270224$ & 7 and 12 \\
\hline RSPL & $74,50 \%$ & Yes & ROA & $1,3473 \mathrm{ROA}+0,154965$ & 2 \\
\hline
\end{tabular}

Chart 8 - Analysis of regression and of correlation of the performance indicators of the Brazilian companies for the year 2005

Source: research data.

All the indicators have significant correlation. Therefore, the performance indicators calculated with basis on the BR GAAP are related to the performance indicators calculated with basis on the US GAAP. By the equation of regression it was possible to calculate the indicators of the Brazilian companies in US GAAP, from the indicators calculated on the accounting statements prepared in accordance with the BR GAAP.

One infers that, in a general way, the performance indicators of the companies analyzed were affected in a significant way, in spite of the Divergences between the Brazilian and American accounting norms presented in Tables 2 to 6 .

To prove the result of the regress and correlation analysis, the equation of regression of Table 8 was applied on the performance indicators calculated with basis on the BR GAAP, to achieve the indicators estimated in US GAAP. This having been done, by means of the QSquared Test, the indicators estimated with the real indicators were compared, calculated on the accounting statements in US GAAP.

The application of the Q-Squared Test for the indicators END, DF and ICP is presented in Table 2. 
Table 2 - Q-Squared Test of significance to the indicators of END, DF and ICP

\begin{tabular}{l|c|c|c|c|c|c|c|c|c}
\hline \multicolumn{1}{c}{ COMPANIES } & $\begin{array}{c}\text { END } \\
\text { US }\end{array}$ & $\begin{array}{c}\text { END } \\
*\end{array}$ & $\chi^{2}$ & $\begin{array}{c}\text { DF } \\
\text { US }\end{array}$ & DF & $\chi^{2}$ & $\begin{array}{c}\text { ICP } \\
\text { US }\end{array}$ & ICP & $\chi^{2}$ \\
\hline Aracruz & 0.92 & 1.18 & 0.06 & 0,48 & 0,54 & 0,01 & 0,79 & 0,81 & 0,00 \\
Bradesco & 9.22 & 8.97 & 0.01 & 0,90 & 0,89 & 0,00 & 0,04 & 0,04 & 0,00 \\
Itaú Holding & 6.61 & 8.03 & 0.25 & 0,87 & 0,88 & 0,00 & 0,09 & 0,04 & 0,09 \\
Brazil Telecom & 1.66 & 2.29 & 0.18 & 0,62 & 0,70 & 0,01 & 0,84 & 0,74 & 0,01 \\
Braskem & 3.50 & 2.26 & 0.68 & 0,78 & 0,69 & 0,01 & 0,69 & 0,79 & 0,01 \\
Cia. Brasileira de Distr. & 1.53 & 1.46 & 0.00 & 0,61 & 0,60 & 0,00 & 0,62 & 0,61 & 0,00 \\
Cemig & 1.31 & 1.64 & 0.07 & 0,57 & 0,62 & 0,00 & 0,74 & 0,71 & 0,00 \\
Sabesp & 1.67 & 0.99 & 0.46 & 0,63 & 0,50 & 0,03 & 0,96 & 0,91 & 0,00 \\
Cia. Vale do Rio Doce & 0.89 & 1.15 & 0.06 & 0,47 & 0,54 & 0,01 & 0,85 & 0,89 & 0,00 \\
CPFL Energia & 1.47 & 1.76 & 0.05 & 0,60 & 0,64 & 0,00 & 0,79 & 0,76 & 0,00 \\
Gerdau & 1.62 & 1.60 & 0.00 & 0,62 & 0,62 & 0,00 & 0,51 & 0,50 & 0,00 \\
Gol & 0.40 & 0.42 & 0.00 & 0,29 & 0,29 & 0,00 & 0,30 & 0,36 & 0,01 \\
Perdigão & 2.00 & 1.83 & 0.02 & 0,67 & 0,65 & 0,00 & 0,47 & 0,49 & 0,00 \\
Sadia & 2.01 & 1.80 & 0.02 & 0,67 & 0,64 & 0,00 & 0,39 & 0,42 & 0,00 \\
Ultrapar Participações & 1.09 & 0.97 & 0.01 & 0,52 & 0,49 & 0,00 & 0,36 & 0,38 & 0,00 \\
Unibanco Holdings & 15.11 & 14.56 & 0.02 & 0,94 & 0,92 & 0,00 & 0,07 & 0,06 & 0,00 \\
Votorantim Cel. e Papel & 1.15 & 1.21 & 0.00 & 0,53 & 0,55 & 0,00 & 0,72 & 0,72 & 0,00 \\
\hline$\sum \chi^{2}$ & 1.88 \\
\hline
\end{tabular}

** Estimated indicator

Source: research data.

The value of $\chi^{2}$ represents the measure of discrepancy between the indicator observed and the indicator expected or estimated. The Q-Squared Test for the indicators of LG, LC, ROA and RSPL is presented in Table 3.

Table 3 - Q-Squared Test for the indicators of LG, LC, RAO and RSPL

\begin{tabular}{|c|c|c|c|c|c|c|c|c|c|c|c|c|}
\hline COMPANIES & $\begin{array}{l}L G \\
U S\end{array}$ & $\begin{array}{l}L G \\
*\end{array}$ & $\chi^{2}$ & $\begin{array}{l}L C \\
U S \\
\end{array}$ & $\begin{array}{l}L C \\
*\end{array}$ & $\chi^{2}$ & $\begin{array}{l}\text { ROA } \\
\text { US }\end{array}$ & $\begin{array}{l}\text { ROA } \\
*\end{array}$ & $\chi^{2}$ & $\begin{array}{l}\text { RSPL } \\
\text { US } \\
\end{array}$ & $\begin{array}{l}\text { RSPL } \\
*\end{array}$ & $\chi^{2}$ \\
\hline Aracruz & 0.66 & 0.54 & 0.03 & 2.26 & 2.17 & 0.00 & 0.13 & 0.13 & 0.00 & 0.21 & 0.32 & 0.04 \\
\hline Bradesco & 1.08 & 1.11 & 0.00 & 2.48 & 1.58 & 0.51 & 0.09 & 0.06 & 0.01 & 0.45 & 0.21 & 0.29 \\
\hline Itaú Holding & 1.08 & 1.13 & 0.00 & 2.49 & 1.63 & 0.45 & 0.09 & 0.08 & 0.00 & 0.42 & 0.23 & 0.16 \\
\hline Brasil Telecom & 0.67 & 0.66 & 0.00 & 0.99 & 1.51 & 0.18 & -0.03 & -0.03 & 0.00 & 0.03 & 0.07 & 0.03 \\
\hline Braskem & 0.67 & 0.60 & 0.01 & 1.32 & 1.62 & 0.05 & 0.09 & 0.07 & 0.00 & 0.32 & 0.22 & 0.04 \\
\hline Cia. Bras. de Distr. & 0.84 & 0.88 & 0.00 & 2.06 & 2.11 & 0.00 & 0.06 & 0.05 & 0.00 & 0.07 & 0.18 & 0.07 \\
\hline Cemig & 0.76 & 0.78 & 0.00 & 0.97 & 1,29 & 0,08 & 0,07 & 0,12 & 0,02 & 0,24 & 0,30 & 0,01 \\
\hline Sabesp & 0.20 & 0.31 & 0.04 & 1.01 & 1,38 & 0,10 & 0,08 & 0,09 & 0,00 & 0,13 & 0,26 & 0,06 \\
\hline Cia. Vale Rio Doce & 0.59 & 0.54 & 0.00 & 1.44 & 1,43 & 0,00 & 0,31 & 0,31 & 0,00 & 0,68 & 0,59 & 0,01 \\
\hline CPFL Energia & 0.71 & 0.71 & 0.00 & 0.91 & 1,29 & 0,11 & 0,11 & 0,11 & 0,00 & 0,22 & 0,29 & 0,02 \\
\hline Gerdau & 0.95 & 0.96 & 0.00 & 2.96 & 2,92 & 0,00 & 0,20 & 0,21 & 0,00 & 0,46 & 0,44 & 0,00 \\
\hline Gol & 2.70 & 2.65 & 0.00 & 2.38 & 2,48 & 0,00 & 0,30 & 0,26 & 0,01 & 0,39 & 0,51 & 0,03 \\
\hline Perdigão & 1.01 & 1.02 & 0.00 & 1.97 & 2,13 & 0,01 & 0,14 & 0,15 & 0,00 & 0,42 & 0,34 & 0,02 \\
\hline Sadia & 1.14 & 1.15 & 0.00 & 1.75 & 2,05 & 0,04 & 0,11 & 0,14 & 0,00 & 0,37 & 0,32 & 0,01 \\
\hline Ultrapar Part. & 1.32 & 1.38 & 0.00 & 3.97 & 4,05 & 0,00 & 0,11 & 0,12 & 0,00 & 0,20 & 0,29 & 0,03 \\
\hline Unibanco Holdings & 1.02 & 1.06 & 0.00 & 2.18 & 1,59 & 0,22 & 0,08 & 0,05 & 0,01 & 0,20 & 0,20 & 0,00 \\
\hline Votorantim Cel Papel & 0.69 & 0.63 & 0.01 & 2.62 & 2,52 & 0,00 & 0,07 & 0,08 & 0,00 & 0,18 & 0,24 & 0,02 \\
\hline$\sum \chi^{2}$ & \multicolumn{3}{|l|}{0.10} & \multicolumn{3}{|l|}{1.77} & \multicolumn{3}{|l|}{0.07} & \multicolumn{3}{|l|}{0.83} \\
\hline
\end{tabular}

Source: research data. 
The Q-Squared Test, with $95 \%$ of reliability and a degree of liberty for 17 observations (number of companies researched), points as a result of significance the maximum value of 26.3 (SPIEGEL, 1977).

As the sum $\left(\sum \chi^{2}\right)$ of all the indicators of Tables 2 and 3 remained below this value, one infers that the correlation presented in Table 8 is valid. With this, it is proved that in spite of the divergences observed between the Brazilian and American accounting norms, the performance indicators are not affected in a significant way, not representing asymmetry of information.

\section{CONCLUSIONS}

The article had the objective of analyzing the impact of the differences between the Brazilian and American accounting norms in the performance indicators of Brazilian companies of corporative governance, covering the 81 Brazilian companies listed in Levels 1 and 2 and in the New Market of Corporative Governance of Bovespa. The intentional sample consisted of the 17 Brazilian companies of corporative governance that in January 2007 presented business of American Depositary Receipts (ADR's) on the NYSE, in which documental research was done, considering the accounting statements of the year of 2005 sent to Bovespa and to the NYSE.

Based on the accounting statements (DC) of the year 2005 sent to Bovespa and to the NYSE of the Brazilian companies of corporative governance with ADR's on the NYSE performance indicators were initially calculated (liquidity, Indebtedness and profitability). In the sequence, the percentage differences between the performance indicators of the respective DC were raised and prepared with basis on the Brazilian norms (BR GAAP) and American (US GAAP).

Concerning the percentage differences in the performance indicators of the Brazilian companies, calculated with basis on the DC sent to Bovespa and those sent to the NYSE, heterogeneous percentage variations were noted since there are positive and negative variations in all the indicators. Apart from this, some companies have significant differences in certain indicators and irrelevant in other indicators. For example, the company Aracruz Celulose S/A has a positive variation in the Return on Net Worth (RSPL) of $85 \%$. On the other hand, Brasil Telecom Participações S/A presented a negative variation in this same index of $121 \%$. Now companies such as Perdigão and Ultrapar had minimum negative variations of approximately $1 \%$ and $2 \%$ respectively.

It is observed that in the individual analysis of each indicator and of each company there are differences greater or lesser, positive or negative. This suggests that the divergences in the accounting measuring and evidencing as a result of the accounting norms affect the performance indicators calculated with basis on the accounting statements prepared according to the Brazilian and American accounting norms. Nevertheless, the greater or lesser impact on each indicator and on each company depends on the existence or not of the elements that register the net worth variations that have differences in the applicable norms and also of their amount.

In the global analysis of the impact of the divergences between BR GAAP and US GAAP on the performance indicators of the companies by means of the analysis of regression and of correlation, significant correlation was noted between the differences in the performance indicators calculated based on the accounting statements sent to Bovespa and to the NYSE. The consistency of the results of the analysis of regression and correlation was tested with the application of the Q-Squared Test of significance, which demonstrated the results found being consistent 
One infers, therefore, that the divergences between the Brazilian and American accounting norms did not affect in a significant way the performance indicators of the analyzed companies. One gathers that asymmetry of information does not occur in the companies of the sample between what is disclosed on Bovespa and on the NYSE.

On the hypothesis of formulated research, based on the statistical analysis, the null hypothesis $\left(\mathrm{H}_{0}\right)$ is rejected and the alternative hypothesis is accepted $\left(\mathrm{H}_{1}\right)$. The alternative hypothesis $\mathrm{H}_{1}$ presupposed that there is correlation between the performance indicators of Brazilian companies of corporative governance calculated based on the accounting statements sent to Bovespa and the performance indicators of the same companies calculated based on the accounting statements sent to the NYSE.

In a general way, one concludes that the performance indicators of the Brazilian companies of corporative governance with ADR's on the NYSE were not affected in a significant way, in spite of the divergences between the Brazilian and American accounting norms. Therefore, although one has found individual differences in performance indicators calculated with basis on the accounting statements prepared according to the Brazilian and American accounting norms, considering the researched sample and the performance indicators selected, one denotes in general that there is no asymmetry of information between what is disclosed on the Bovespa and on the NYSE.

The individual differences found need to be considered by the analysis since the positive and negative variations shown in all the indicators can distort the analysis if there is compensation between both. The fidelity of the analysis in the sense of representing the economic-financial reality of the companies will depend on the amount of the value that will show in each accounting account that causes the variation and the respective compensation between the positive and negative variations.

For future studies, it is recommended that other companies are investigated to check the differences in the performance indicators of these companies in the conversion of their statements of BR GAAP to US GAAP. It is also recommended that other differences in the identification and measuring of events are investigated as a result of the diversity in the accounting norms of countries and, as a consequence, other performance indicators affected are considered. Another suggestion is to compare the indicators calculated with those that would be calculated if the International Norms of Accounting were used (International Accounting Standard - IAS), known as IFRS (International Financial Reporting Standard), published by IASB (International Accounting Standards Board).

\section{REFERENCES}

ASSAF NETO, Alexandre. Structure and analysis of balance sheets: an economicalfinancial focus. 7. ed. São Paulo: Atlas, 2002.

BRAZIL. Law no. 11.638/07, of December $18^{\text {th }}$, 2007. Alters, revokes and introduces new provisions to the Joint Stock Company Law (Law no. 6.404, of $15^{\text {th }}$ of December 1976).

BORGES, Luiz Ferreira Xavier; SERRÃO, Carlos Fernando de Barros. Aspects of modern corporative governance in Brazil. BNDES Magazine. Rio de Janeiro, v. 12, n. 24, p. 111-148, Dec. 2005.

BOUDON, Raymond. The methods in sociology. São Paulo: Ática, 1989.

$\begin{aligned} & \text { FINANCIAL ACCOUNTING STANDARDS } \\ & \text { research } \\ & \text { <http://www.fasb.org/st/summary/stsum2.shtml }>\text {. Access on: Apr. 20. } 2008 .\end{aligned}$


FINANCIAL ACCOUNTING STANDARDS BOARD (FASB). SFAS 133 Accounting for derivative instruments and hedging activities, June 1998. Available on: <http://www.fasb.org/pdf/fas133.pdf>. Access on: Apr. 20. 2008.

FINANCIAL ACCOUNTING STANDARDS BOARD (FASB). SFAS 142 Goodwill and other intangible assets. Available on: <http://www.fasb.org/st/summary/stsum142.shtml >. Access on: Apr. 20. 2008.

GIL, Antonio Carlos. How to prepare research projects. 4. ed. São Paulo: Atlas, 2002.

GITMAN, Lawrence J. Financial Administration. 2. ed. São Paulo: Bookman, 2000.

BRAZILIAN INSTITUTE OF CORPORATIVE GOVERNANCE (IBGC). Brazilian Code of best practices of corporative governance. 3. ed., 2004. Available on: <http://www.ibgc.org.br>. Access on: Sep. 05. 2006.

LA PORTA, Rafael; LOPEZ-DE-SILANES, Florencio; SHLEIFER, Andrei. Corporate ownership around the world. Journal of Finance, vol. liv. n. 2, Apr. 1999.

LA PORTA, Rafael; LOPEZ-DE-SILANES, Florencio; SHLEIFER, Andrei; VISHNY, Robert W. Law and finance. Journal of Political Economy, 1998. Available on: $<$ http/www.wcfia.harvard.edu/papers/law_finance.pdf>. Access on: Sep. 05. 2006.

LODI, João Bosco. Corporative governance: the government of the company and the board of directors. Rio de Janeiro: Campus, 2000.

MACMILLAN, Hugh; TAMPOE, Mahen. Strategic management: process, content and implementation. Oxford: Oxford University Press, 2000.

MAROCO, João. Statistical Analysis: with use of the SPSS. 2. ed. Lisboa: Edições Sílabo, 2003.

MATARAZZO, Dante C. Financial analysis of balance sheets: basic and management approach. 6. ed. São Paulo: Atlas, 2003.

NIYAMA, Jorge K. international Accounting. São Paulo: Atlas, 2005.

PRICEWATERHOUSECOOPERS (PWC). Similarities and differences IFRS $\mathbf{x}$ USGAAP $\mathbf{x}$ accounting practices adopted in Brazil. Available on: <http://www.pwc.com.br $>$. Access on: Nov. 21. 2006.

RICHARDSON, Roberto Jarry. Social Research: methods and techniques. 3. ed. São Paulo: Atlas, 1999.

SCHRICKEL, Wolfgang K. Financial Statements: opening the black box. São Paulo: Atlas, 1997.

SIEGEL, Sidney. Non-parametric statistics for the behavioral sciences. São Paulo:

McGraw-Hill, 1975.

SPIEGEL, Murray R. Statistics: summary of the theory. São Paulo: MacGraw-Hill, 1977.

SPIEGEL, Murray R. Statistics. 3. ed. São Paulo: Makron Books, 1993.

WEFFORT, Elionor F. J. Brazil and the international accounting harmonizing: influences of the legal and educational systems, of the culture and of the market. São Paulo: Atlas, 2005.

WRIGHT, Peter; KROLL, Mark; PARNELL, John. Strategic Administration: Concepts. São Paulo: Atlas, 2000. 